\title{
PEMANFAATAN TEKNOLOGI INFORMASI BERBASIS ANDROID SEBAGAI MEDIA PENYAMPAIAN INFORMASI KESEHATAN DI POSYANDU
}

\author{
Intan Mutia'), Wahyu Nur Cholifah' ${ }^{2)}$, Yulianingsih ${ }^{3)}$
}

Program Studi Informatika, Fakultas Teknik dan Ilmu Komputer, Universitas Indraprasta PGRI

\begin{abstract}
Abstrak
Pemerintah tidak semata-mata bertanggung jawab dalam hal upaya peningkatan peran dan fungsi Posyandu, namun semua komponen yang ada di masyarakat, termasuk Kader. Peran Kader dalam penyelenggaraan Posyandu sangat besar karena selain sebagai pemberi informasi kesehatan kepada masyarakat. Juga sebagai penggerak masyarakat untuk datang ke Posyandu dan melaksanakan perilaku hidup bersih dan sehat. Proses penyebaran informasi di posyandu umumnya masih dalam bentuk pamflet dan buku panduan berwarna berukuran A3 (Flipchart). Buku panduan ini merupakan sumber utama posyandu dalam memberikan informasi layanan kesehatan kepada warga, hal ini selain merepotkan kader juga monoton dalam penyampaian sehingga dibutuhkan keahlian dan kreatifitas kader dalam menyampaikan materi yang baru. Tujuannya merupakan pelatihan peningkatan keterampilan kader posyandu dalam menyebarkan materi layanan kesehatan yang sudah diolah melalui ponsel Android, Kader posyandu lebih mudah dalam mengolah data layanan masyarakat menggunakan ponsel Android, Kader posyandu mampu membuat materi layanan kesehatan untuk kegiatan berkala penyuluhan masyarakat yang sudah dibuat untuk disebarluaskan menggunakan media Android. Hasil yang diperoleh dengan adanya pelatihan ini dapat membantu meningkatkan kinerja Kader Posyandu dalam menyebarluaskan informasi kesehatan masyarakat dengan lebih mudah, cepat dan efisien.
\end{abstract}

Kata Kunci: Media informasi, Posyandu. Teknologi Informasi, Android, Kesehatan

\begin{abstract}
The government is not solely responsible for efforts to improve the role and function of Posyandu, but for all components in the community, including cadres. The role of cadres in implementing Posyandu is very large because they are not only as providers of health information to the community but also as a motivator for the community to come to Posyandu and carry out a clean and healthy lifestyle. Generally, the process of disseminating information at posyandu is still in the form of A3 size pamphlets and color manuals (flipchart). This guidebook is the main source of posyandu for providing information on health services to residents. It is hasle and monotonous in presenting so that cadres' expertise and creativity are needed in delivering new materials. The goal is training to improve the skills of posyandu cadres in distributing health service materials via Android phones, Posyandu cadres are easier to process public service data using Android phones, Posyandu cadres are able to make health service materials for periodic community activities to be disseminated using Android media. The results obtained with this training can help improve the performance of Posyandu cadres in disseminating public health information more easily, quickly and efficiently.
\end{abstract}

Keywords: Information Media, Posyandu. Information Technology, Android, Health

Correspondence author: Intan Mutia, as_syifaraa@gmail.com, Jakarta, Indonesia 


\section{PENDAHULUAN}

Upaya peningkatan peran dan fungsi Posyandu bukan semata-mata tanggungjawab Pemerintah saja, namun semua komponen yang ada di masyarakat, termasuk Kader (Saepudin, Rizal, \& Rusman, 2017). Peran Kader dalam penyelenggaraan Posyandu sangat besar karena selain sebagai pemberi informasi kesehatan kepada masyarakat juga sebagai penggerak masyarakat untuk datang ke Posyandu dan melaksanakan perilaku hidup bersih dan sehat (Kesehatan \& RI, 2012).

Beberapa kendala di lapangan yang sering terjadi dalam layanan administrasi Posyandu adalah SDM atau Kader yang kurang berkompeten serta sistem dokumentasi data dan informasi kurang memadai (Fithria \& Azmi, 2015). Kompetensi Kader diwujudkan dengan penguasaan layanan seperti pengukuran Balita (berat, lila, lika, lida), penyuluhan dan konsultasi KIA, Gizi, vitamin dan imunisasi dimulai dari persiapan, kegiatan, dan pasca layanan Posyandu (Dewi, 2017).

Posyandu Melati IX merupakan wadah layanan kesehatan masyarakat yang di khususkan untuk melayani kesehatan ibu dan anak wilayah RW 08 Perumahan Binong Permai Blok N, Karawaci Tangerang. Adapun bentuk layanan kesehatan ibu dan anak yang diberikan di Posyandu Melati IX antara lain KIA (Kesehatan Ibu Dan Anak), KB, imunisasi, gizi, pencegahan dan penanggulangan diare dan penyuluhan kesehatan. Jumlah peserta yang memperoleh layanan kesehatan di wilayah Posyandu Melati IX kurang lebih ada 70 orang yang terdiri dari Ibu dan anak, ditambah 8 Kader dan pelakasanaan Posyandu di minggu pertama setiap bulannya.

Dalam melakukan penyuluhan kesehatan yang dilakukan oleh Kader Posyandu Melati IX kepada masyarakat selama ini masih manual dimana bentuk informasi yang disampaikan menggunakan lembar balik (FlipChart). Lembar balik merupakan salah satu media promosi kesehatan yang dikeluarkan oleh Pusat Promosi Kesehatan Departemen Kesehatan RI tahun 2008, yang digunakan oleh Kader sebagai alat bantu dalam menyampaikam informasi dalam hal ini penyuluhan kesehatan kepada masyarakat. Media lembar balik berisi informasi berbentuk gambar atau grafik. Media lembar balik terdiri dari 2 bagian yaitu bagian muka berisi gambar untuk diperlihatkan peserta penyuluhan, dan bagian belakang berisikan tulisan yang menjelaskan gambar untuk dibaca oleh Kader. Penyuluhan diberikan oleh Kader kepada masyarakat secara bertahap yang di sesuaikan dengan kebutuhan atau masalah yang ada (Iswarawanti, 2010).

Cara Kader Posyandu Melati IX dalam memberikan penyuluhan kesehatan yaitu dengan tatap muka secara langsung dengan masyarakat dan menjelaskan apa yang menjadi topik yang akan dibahas, dengan meletakkan media lembar balik di atas meja (jika ada), dengan posisi Kader yang dapat dilihat oleh semua masyarakat (peserta penyuluhan) yang kemudian dilanjutkan dengan sesi tanya jawab yang berkenaan dengan topik kesehatan yang sedang dibahas. 


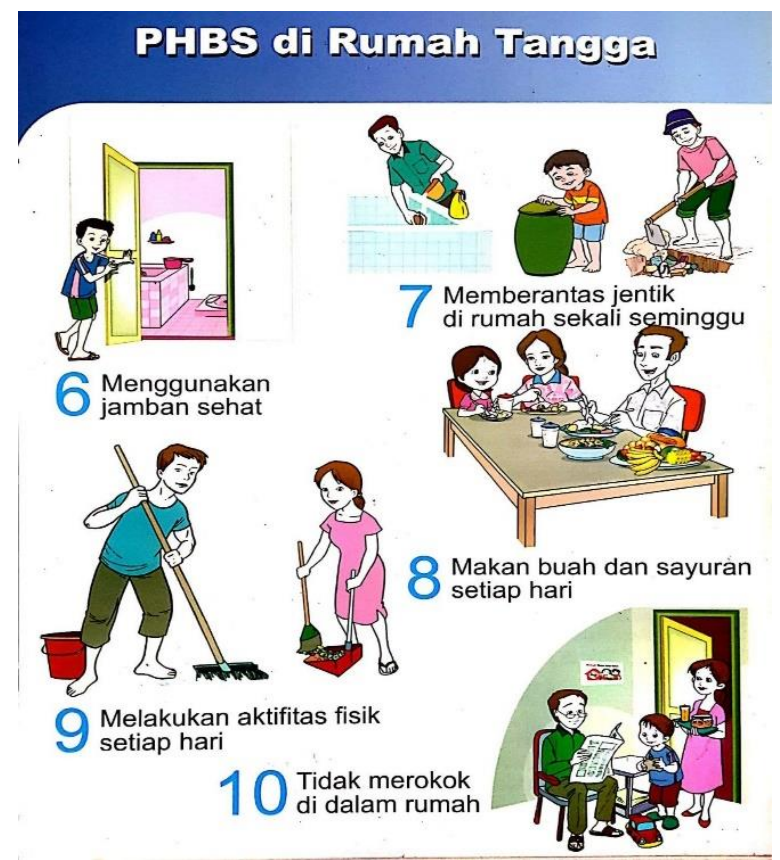

Gambar 1 FlipChart Lembar Balik

Pada saat ini, proses penyebaran informasi kesehatan kepada masyarakat berupa penyuluhan dengan menggunakan media lembar balik (FlipChart) yang dikeluarkan oleh Pusat Promosi Kesehatan Departemen Kesehatan RI. Media lembar balik yang digunakan oleh Kader dalam memberikan penyuluhan kepada masyarakat ukurannya besar ... x ... dengan berat kurang lebih ... per media promosi kesehatan, hal ini tidaklah efisian dan efektif mengingat media seperti tersebut diatas pada zaman teknologi sekarang ini sudah mulai ditinggalkan. Dibutuhkan pengalihan teknologi penyampaian materi kesehatan masyarakat dari bentuk media kertas dalam hal ini lembar balik ke teknologi informasi dengan menggunakan media android dalam menyampaikan penyuluhan kesehatan kepada masyarakat (Utomo \& Amin, 2014). Di Posyandu Melati IX, komunikasi sesama Kader sudah menggunakan smartphone, dimana semua informasi terbaru yang diperoleh dari hasil pertemuan PKK Kelurahan Binong dapat langsung di bagikan oleh Ketua Posyandu ke group Pengurus Posyandu Melati IX, dengan demikian Kader mendapatkan informasi terupdate dalam waktu yang relatif singkat dan cepat. Guna mengatasi kendala tersebut maka perlu dikembangkan sebuah sistem informasi terotomasi berbasis komputer, yang fleksibel untuk pengolahan data dan menyediakan informasi (Supriyanto \& Hartono, 2017).

Berdasarkan permasalahan di atas, maka di dalam penelitian ini mengusulkan adanya inovasi di dalam penyuluhan kesehatan memanfaatkan teknologi yang dalam hal ini adalah teknologi berbasis Android. Hal ini dianggap penting karena fakta bahwa masyarakat Indonesia saat ini sudah akrab dengan gadget berbasis Android sehingga akan mempermudah kinerja para kader. Adapun tujuan penelitian ini merupakan pelatihan peningkatan keterampilan kader posyandu dalam menyebarkan materi layanan kesehatan yang sudah diolah melalui ponsel Android, Kader posyandu lebih mudah dalam mengolah data layanan masyarakat menggunakan ponsel Android, Kader posyandu mampu membuat materi layanan kesehatan untuk kegiatan berkala penyuluhan masyarakat yang sudah dibuat untuk disebarluaskan menggunakan media Android. 


\section{METODE PELAKSANAAN}

Dukungan Teknologi Informasi dan Komunikasi (TIK) pengolahan data manual dapat digantikan dengan sistem informasi berbasis Komputer (Prigianata, 2013). Agar para kader dapat memahami kemudahan dalam menggunakan ponsel Android dalam membagikan informasi masyarakat terutama kesehatan, maka dirancang dan dilaksanakan pelatihan yang melibatkan Kader-Kader Posyandu Melati IX yang bertempat di Posyandu Melati IX dengan lokasi di Perumahan Binong Permai Blok N RT 07/08 Karawaci Tangerang Banten. Prosedur pelatihan yang dilaksanakan sebagai berikut:

1. Melakukan pertemuan dengan Tim Penggerak PKK RW 08, untuk menyampaikan maksud kedatangan Tim Abdimas ke lokasi. Dan sasaran yang diberikan adalah dua mitra posyandu di bawah binaan PKK RW 08. Namun mitra yang bersedia adalah Kader Posyandu Melati IX.

2. Tim Abdimas menganalisa kebutuhan Mitra, mengumpulkan bahan dan materi yang akan digunakan pada pelatihan kepada Kader Posyandu.

3. Pelaksanaan abdimas. Mitra berpartisipasi dengan menyediakan materi kesehatan yang akan diolah, Mitra juga mengumpulkan Kader aktif yang akan dilatih aplikasi powerpoint dan Android.

4. Pelatihan diberikan kepada Kader Posyandu Melati IX di lokasi yang sudah disiapkan oleh pihak Mitra Abdimas, yaitu diruangan pelaksanaan Posyandu Melati IX.

5. Pelaporan Kegiatan. Melakukan sejumlah analisa terhadap hasil kegiatan dan mengambil simpulan untuk dapat dilakukan perbaikan pada kegiatan abdimas selanjutnya.

\section{HASIL DAN PEMBAHASAN}

Dalam memberikan pelatihan membuat materi posyandu secara interaktif menggunakan media ponsel Android yang dilakukan Tim Abdimas terlihat bahwa Kader Posyandu masih kesulitan dalam pengoperasian ponsel Android yang dimiliki, masih ada Kader yang belum menggunakan ponsel Android, namun memiliki ketertarikan dalam pelasanaan pelatihan ini.

Para Kader Posyandu Melati IX di wilayah Perumahan Binong Permai Blok N, RT07/ 08 yang terlibat dalam pelatihan sejumlah 10 orang termasuk didalamnya Ketua PKK RW 08 dan 1 orang bidan puskesmas yang ditugaskan.

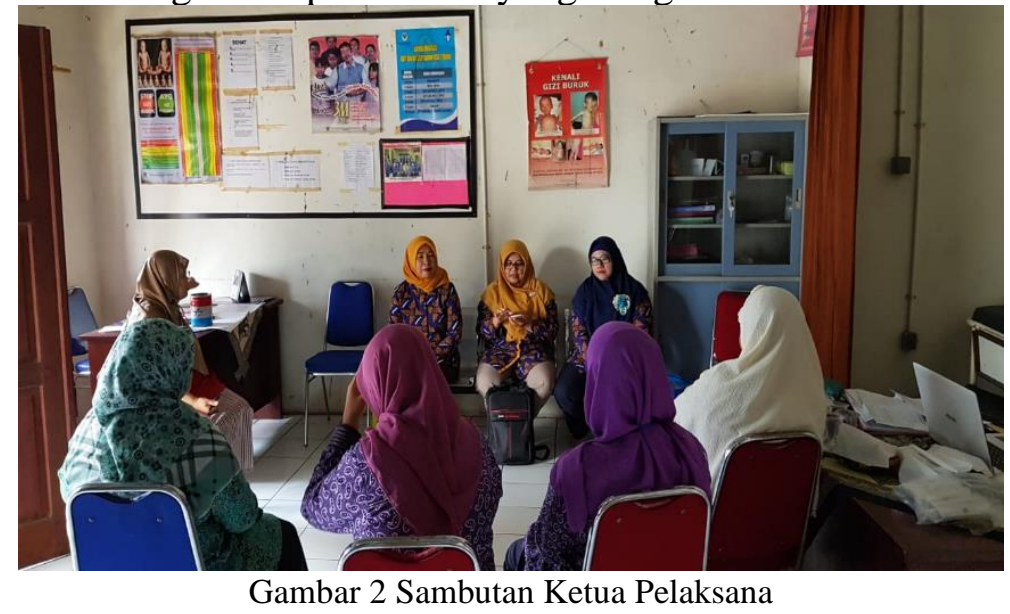


Terlihat dinamika dalam pelatihan ponsel Android ini sehingga untuk meminimalisir kesulitan yang dialami maka solusi yang diberikan kepada Kader Posyandu Melati IX adalah menyiapkan materi layanan kesehatan yang sudah diolah untuk digunakan pada ponsel Android Kader sehingga lebih mudah dalam mengolah data layanan masyarakat. Kader Posyandu Melati IX mudah membagikan materi layanan kesehatan untuk setiap kegiatan posyandu secara berkala dengan menggunakan media Android dalam setiap kegiatannya. Kegiatan pelatihan dengan Kader Posyandu Melati IX didokumentasikan sebagai berikut:

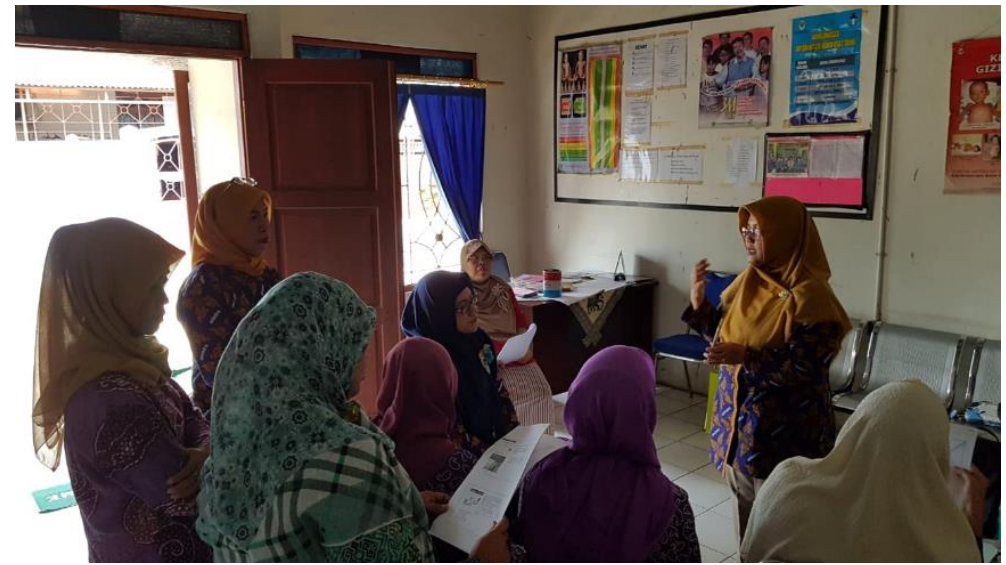

Gambar 3 Pengenalan Dasar Android

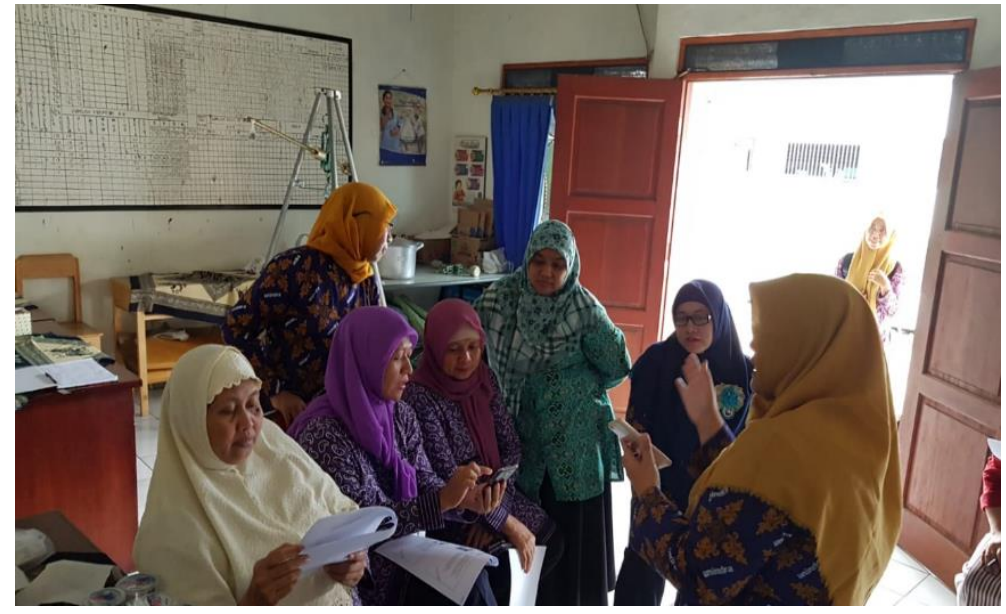

Gambar 4 Pelatihan Penggunaan Android

Hasil pelatihan yang telah dicapai dari kegiatan yang dilakukan oleh Tim Abdimas terhadap Kader Posyandu Melati IX mendapat respon positif, pelatihan berjalan dengan lancar sesuai dengan harapan dan terjalin komunikasi yang baik dengan sangat terbuka. Ditemukan pula bahwa pelatihan berbasis Android ini merupakan sebuah terobosan baru yang efektif dan efisien sebagai media pemberian informasi kesehatan masyarakat. Dengan adanya kegiatan pelatihan pemanfaatan teknologi informasi sebagai media penyampaian informasi layanan kesehatan kepada masyarakat membuat Kader Posyandu Melati IX dapat memahami dan mengimplentasikan ilmu yang di dapat bahwa menggunakan teknologi informasi berbantuan media android dapat memberikan kemudahan dan meningkatkan layanan Kader Posyandu Melati IX dalam memberikan informasi kepada masyarakat. Pelatihan berbantuan media android memberikan 
kemudahan bagi Kader Posyandu Melati IX dalam membuat materi kesehatan dan mengolah data kesehatan sehingga tidak perlu kerepotan dengan lembar balik (flipchart) yang selama ini digunakan Kader Posyandu Melati IX dalam penyampaikan informasi kepada masyarakat.

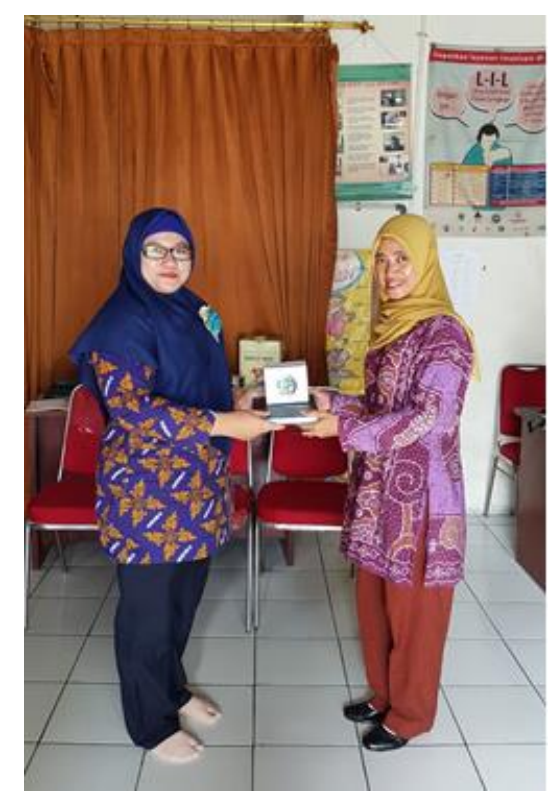

Gambar 5 Penutupan Kegiatan Pengabdian

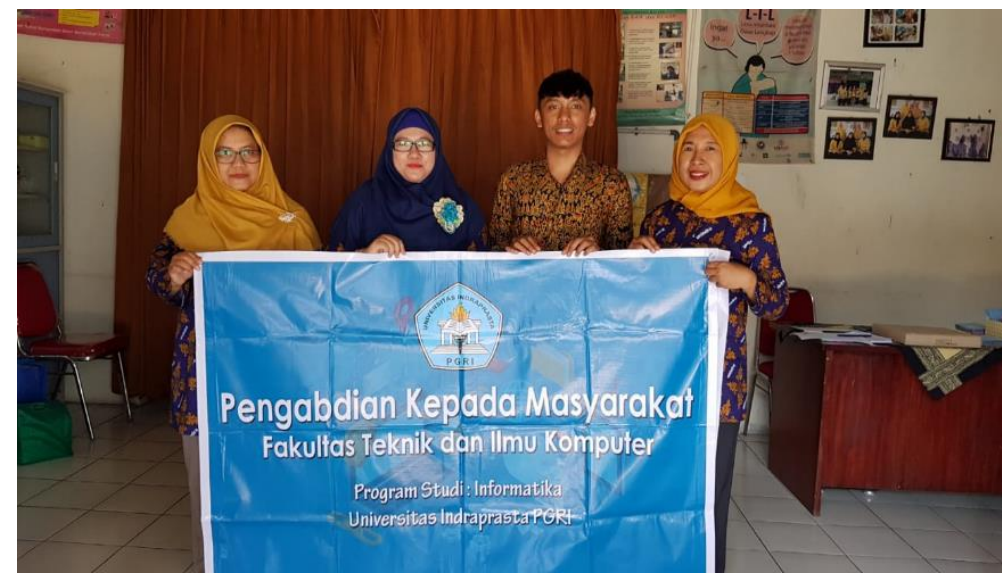

Gambar 6 Tim Pengabdian Kepada Masyarakat

\section{SIMPULAN}

Adapun hasil dari kegiatan pengabdian kepada masyarakat yang telah dilakukan di Posyandu Melati IX, dapat ditarik suatu simpulan bahwa pelatihan yang di lakukan oleh Tim Abdimas di Posyandu Melati IX berjalan dengan baik dan Kader Posyandu menerima pengetahuan baru dalam hal pemanfaatan media android sebagai media penyampaian informasi. Pelatihan ini sesuai dengan tujuan telah meningkatkan keterampilan kader posyandu dalam menyebarkan materi layanan kesehatan yang sudah diolah melalui ponsel Android, sehingga Kader posyandu lebih mudah dalam mengolah data layanan masyarakat menggunakan ponsel Android. Pelatihan ini membuat Kader 
posyandu dapat menggunakan media Android dalam menyebarluaskan kegiatan berkala penyuluhan masyarakat yang sudah dibuat.

\section{DAFTAR PUSTAKA}

Dewi, D. S. (2017). Peran Komunikator Kader Posyandu Dalam Meningkatan Status Gizi Balita Di Posyandu Nurikelurahan Makroman Kecamatan Sambutan Kota Samarinda. EJournal Ilmu Komunikasi, 5(1), 272-282.

Fithria, \& Azmi, N. (2015). HUBUNGAN PEMANFAATAN POSYANDU DENGAN STATUS GIZI BALITA DI KECAMATAN KOTA JANTHO. Idea Nursing Journal, VI(1), 1-6.

Iswarawanti, D. N. (2010). KADER POSYANDU : PERANAN DAN TANTANGAN PEMBERDAYAANNYA DALAM USAHA PENINGKATAN GIZI ANAK DI INDONESIA. Manajemen Pelayanan Kesehatan, 13(04), 169-173.

Kesehatan, K., \& RI. (2012). Ayo Ke Posyandu Setiap Bulan. In Pusat Promosi Kesehatan.

Prigianata, M. M. (2013). Sistem Informasi Posyandu Guna Mempermudah Pencatatan Pemeriksaan Berbasis Web. Journal of Information and Technology, 1(1).

Saepudin, E., Rizal, E., \& Rusman, A. (2017). Peran Posyandu Sebagai Pusat Informasi Kesehatan Ibu dan Anak. Record and Library Journal, 3(Juli - Desember 2017), 201-208.

Supriyanto, A., \& Hartono, B. (2017). PERAN TEKNOLOGI INFORMASI BAGI KADER POSYANDU. Seminar Nasional Vokasi Dan Teknologi (SEMNASVOKTEK), 360-365. Denpasar-Bali.

Utomo, T., \& Amin, I. H. Al. (2014). Sistem informasi penyuluhan posyandu berbasis web mobile. Dinamika Informatika, 6(2), 131-141. 